\title{
ПРОФАЙЛІНГ ОСОБИСТОСТІ: ЧИ Є ЙОМУ МІСЦЕ В СУЧАСНІЙ ПЕДАГОГІЧНІЙ НАУЦІ?
}

У статті проаналізовано методологічні основи наукового розуміння предмету профайлінгу, його понятійно-категоріальний апарат, висвітлено генезу та основні напрями розвитку профайлінгу, зроблено спробу з'ясувати місие $і$ роль профайлінгу в педагогічній теорії та практиці. Науковий пошук здійснювався з використанням комплексу методів: загальнонаукових аналітичний, ретроспективний та порівняльний аналіз наукової літератури, для з 'ясування природи досліджуваного феномену; хронологічний - для розгляду явища у динамічі; термінологічний аналіз - для уточнення базових понять дослідження; узагальнення та систематизація наявного досвіду з зазначеної проблеми - для формулювання власних поглядів на місце і роль профайлінгу у сучасній педагогіиі.

Вивчення довідникової літератури та наукових публікащуій дозволило, у периу чергу, встановити відсутність єдиного науково обгрунтованого визначення поняття «профайлінг» та значне розмаӥття підходів сучасних дослідників до його категоризації, щзо пояснюємо, з одного боку, малодослідженістю явища у вітчизняному науковому просторі, та, з іншого боку, складністю отримання вірогідних верифікованих даних. Нами було запропоновано власне розуміння понять: профайлінг ми розглядаємо як певний комплекс взаємопов'язаних діагностичних прочедур, щзо використовується для складання психологічного портрету людини з наступною типологізацією ї̈ особистості та поведінки, а «педагогічний профайлінг» як комплекс взаємопов'язаних діагностичних прочедур, щуо використовується в освітньому процесі для складання психологічного портрету здобувача освіти з метою прогнозування його академічної поведінки та подальшої професійної діяльності. Дискусійними залишилися питання щуодо: рівня науковості изього знання; вимог до рівня знань й умінь профайлерів, їх підготовки; відсутності чіткого та уніфікованого поділу особистостей людей на типи, складності у створенні їх профілю; можливостей опертя на теорію особистостей О. Лазурського у вироблені принщипів та підходів педагогічної профілізациї особистості.

Ключові слова: особистість, профайлінг, види профаайлінгу, типологічний профайлінг, теорія особистості О. Лазурського . 
Leontieva I. V. Personality profiling: does he have a place in modern pedagogical science? The article analyzes the methodological foundations of scientific understanding of the subject of profiling, its conceptual and categorical apparatus, highlights the genesis and main directions of profiling, attempts to clarify the place and role of profiling in pedagogical theory and practice. Scientific research was carried out using a set of methods: general scientific - analytical, retrospective and comparative analysis of scientific literature - to clarify the nature of the phenomenon under study; chronological - to consider the phenomenon in dynamics; terminological analysis - to clarify the basic concepts of the study; generalization and systematization of existing experience on this issue - to formulate their own views on the place and role of profiling in modern pedagogy. The study of reference books and scientific publications allowed, first of all, to establish the lack of a single scientifically sound definition of "profiling" and a significant variety of approaches of modern researchers to its categorization, which is explained, on the one hand, by little research in the domestic scientific space. hand, the difficulty of obtaining reliable verified data. We proposed our own understanding of the concepts: we consider profiling as a set of interrelated diagnostic procedures used to compile a psychological portrait of a person followed by typology of his personality and behavior, and "pedagogical profiling" as a set of interconnected diagnostic procedures used in educational process to compile a psychological portrait of the student in order to predict his academic behavior and further professional activity. Questions about the level of scientific knowledge of this knowledge remained controversial; requirements for the level of knowledge and skills of profilers, their training; lack of clear and unified division of people's personalities into types, difficulty in creating their profile; possibilities of relying on the theory of personalities of O. Lazursky in the developed principles and approaches of pedagogical profiling of personality.

Keywords: personality, profiling, types of profiling, typological profiling, O. Lazursky's theory of personality.

Вступ. Нещодавно, вивчаючи зміст робочих програм навчальних дисциплін для здобувачів третього (освітньо-наукового) рівня вищої освіти спеціальності 011 - Освітні, педагогічні науки, ми виявили цікавий нюанс. Серед тем, запропонованих здобувачам для вивчення в межах однієї 3 дисциплін, змістовий модуль якої має назву «Психологія професійного розвитку», була тема «Психологія професійного профайлінгу», яка охоплювала такі аспекти: поняття професійного профайлінгу, методи створення професійного портрету особистості, основні напрями підвищення ефективності професійної діяльності, профайлінг у науковій сфері діяльності тощо. Не будемо перераховувати у повному обсязі основні поняття цієї теми, а також назву цієї програми, зазначимо лише, що вона розроблена й використовується в освітньому процесі з 2018 року.

Спробуємо пояснити свій інтерес. Ще донедавна технологія профайлінгу використовувалася виключно у криміналістиці для складання психологічного 
портрету злочинця та прогнозування його подальшої поведінки 3 метою запобігання іiі негативних проявів. Профілювання (від англійського слова «profile» - профіль, характеристика, особиста історія, особиста справа) найчастіше використовується у пошуку серійних гвалтівників та вбивць, а також для ідентифікації грабіжників, терористів та кіберзлочинців. I хоча в сучасних умовах психологічний профайлінг знайшов свою нішу у системі людинознавчих наук та набув видового розмаїття (бізнес-профайлінг, банківський профайлінг, кадровий (HR) профайлінг, авіаційний та інших видів транспорту профайлінг (залізничний, річковий, морський, авто), профайлінг митний та прикордонний, готельний та сімейний, громадського правопорядку та аудит-профайлінг, кримінально-оперативний та судовий, профайлінг відносин тощо).

Останнім часом уміння фахівця профілювати ти чи інші об'єкти відкриває перед ним усе нові варіанти докладання зусиль: у маркетингу, у рекламній сфері, у художньому та театральному мистецтві, іншими словами, у тих сферах професійної діяльності, які орієнтовані на задоволення потреб та інтересів споживачів послуг. Досвідчений профайлер здатен на основі аналізу статистичних даних, запитів, інтересів, типової поведінки споживачів скласти їх психологічний портрет, спрогнозувати поведінку й запропонувати способи персоналізації послуг для обраної аудиторії. I хоча освітня галузь сьогодні теж зорієнтована на надання споживачам (здобувачам освіти) широкого кола послуг, тим не менше явище профайлінгу для неї все ще не характерне, а тому потребує більш детального вивчення й аналізу.

Мета та завдання. Метою нашої статmієспроба визначити місце профайлінгу в системі педагогічного знання,для досягнення якої ми вирішуватимемо такі завдання: окреслити понятійно-категоріальний апарат профайлінгу, висвітити його генезу та основні напрями розвитку, з'ясувати місце і роль профайлінгу в сучасній педагогічній теорії та практиці.

Методи дослідження. Науковому пошуку сприяло використання на різних етапах дослідження комплексу методів: загальнонаукові методи аналітичний, ретроспективний та порівняльний аналіз наукової літератури, що дав змогу з'ясувати природу досліджуваного феномену; хронологічний, що дав змогу розглядати розвиток явища у динаміці; термінологічний аналіз для уточнення базових понять дослідження; узагальнення та систематизація наявного досвіду з зазначеної проблеми для формулювання власних поглядів на місце і роль профайлінгу у сучасній педагогіці.

Результати. Насамперед зазначимо, що, опрацьовуючи довідкову літературу: «Психологічна енциклопедія» (Psykholohichna entsyklopediia, 2006), «Словник іншомовних слів» (Bybyk \& Siuta, 2006), «Короткий словник актуальних педагогічних термінів» (Flehontova, 2013), «Енциклопедія освіти» (Entsyklopediia osvity, 2008), «Педагогічний словник» (Yarmachenko, 2001), «Український педагогічний словник» (Honcharenko, 1997), ми не знайшли жодної згадки про термін «профайлінг», хоча у періодичних виданнях це поняття аналізується та розтлумачується. 
Зауважимо, що більшість опрацьованих нами періодичних видань $є$ російськомовними, що пояснюється малодослідженістю цього питання у вітчизняному науково-педагогічному просторі. Наведемо декілька типових визначень цього поняття. У статті «Значення профайлінгу в сучасному світі. Технологія виявлення неконгруентності» (Merzlikin, 2015) профайлінг визначається як новий напрям у психологічній науці, який дозволяє розшифровувати невербальні компоненти, що використовуються в процесі міжособистісного спілкування задля виявлення осіб, схильних до протиправних дій.

Авторка статті «Комерційний профайлінг як технологія управління» (Martseva, 2014) наводить дещо схоже 3 попереднім варіантом визначення: «профайлінг - це поняття, що позначає сукупність психологічних методів й методик оцінки й прогнозування поведінки людини на основі аналізу найбільш інформативних окремих ознак, характеристик зовнішності, невербальної та вербальної поведінки». Публікація «Експертний профайлінг як сфера професійної діяльності психолога-практика» (Arpentieva, 2016) містить більш широке та грунтовне формулювання цього поняття: «профайлінг - це комплекс соціально-психологічних методик для діагностики особистісних особливостей, прихованих мотивів та оцінки наданої суб'єктом інформації, що грунтуються на оцінці його невербальної, вербальної та субвербальної поведінки; для прогнозування сценаріїв розвитку ситуацій та відношень, вчинків, моделей поведінки й спілкування людини».

Розвідки, присвячені проблемі профайлінгу як сучасної методики діагностики бізнес-процесів (Martseva, 2012), дозволили авторці визначити профайлінг як процедуру профілювання особистості, що передбачає іiі віднесення за низкою невербальних ознак до одного з двох типів особистості: безпечної чи небезпечної, залежно від соціального оточення та контексту. Наведені визначення поняття «профайлінг», як ми вже зазначали, є найбільш типовими, тому, підсумовуючи результати термінологічного аналізу зазначимо, що у сучасному науковому просторі профайлінг розглядається як певний комплекс взаємопов'язаних діагностичних процедур, що використовується для складання психологічного портрету людини 3 наступною типологізацією іiі особистості та поведінки. Безумовно, ми не претендуємо на унікальність та повноту сформульованого нами визначення розглядуваного поняття, воно може і повинно стати предметом подальших наукових дискусій, проте, вважаємо його таким, що $\epsilon$ універсальним для різних галузей знань, у тому числі педагогічного.

Другим завданням, що ми ставили перед собою у своїх розвідках, було 3'ясування генези та основних напрямів розвитку профайлінгу. Вважаємо за необхідне зазначити, що у ході дослідження ми дійшли висновку - профілізація особистості має давню історію, хоча термін «профайлінг» і з'явився порівняно нещодавно, а його розвиток відбувався паралельно у двох напрямах: психологічному та криміналістичному, що час від часу між собою 
перетиналися, звідси i деяка плутанина iз понятійно-категоріальним та методологічним апаратом.

У результаті наших пошуків ми встановили, що загалом, першою задокументованою згадкою про складання психологічного портрету й пошук на його основі злочинця $є$ лист-відповідь Томаса Бонда помічнику комісара служби столичної поліції серу Роберту Андерсону від 25 жовтня 1888 року, в якому британський хірург надає свій експертний медичний висновок, зроблений за результатами патологоанатомічного вивчення жертв Джека Різника. У листі він доволі детально описує деякі особливості поведінки та побуту злочинця, за якими його доволі швидко упіймали.

Загалом же, перші спроби описати психотипи людей та вивести на основі цих «портретів» певні прогнози щодо їх поведінки припадають ще на часи Давньої Греції. Найбільш відомою типологією є класифікація людей за типом темпераменту, запропонована Гіппократом: холерик, сангвінік, меланхолік та флегматик. Аристотель також намагався прогнозувати поведінку людей, залежно від того, до якого психотипу (персоналіст, процесор, філософ, предметник, хронолог, намісник) вони належать. У антропологічній теорії Чезаре Ламброзо виокремлено чотири типи злочинців: вроджені, випадкові, душевнохворі та 3 пристрасті. Карл Юнг ділив людей на мислячих, відчуваючих, інтуїтивних та чутливих.

У Ернста Кречмера основою для поділу людей був тип статури: астенік, атлетик та пікнік (сьогодні до цього переліку додають ще диспластика - прим. I. Л.). Вільям Шелдон теж пропонує три типи особистості: мезоморф, ектоморф та ендоморф. Карл Леонгард виокремив шість типів: гіпертимний, дистимічний, афективно-лабільний, нестійкий, тривожний, афективно-екзальтований, емотивний. Натомість Петро Ганнушкін окреслив дев’ять груп: циклоїди, астеніки, шизоїди, параноїки, епілептоїди, істерики, нестійкі, антисоціальні та конституційно-нерозумні. Андрій Личко класифікує особистості за типом акцентуацій характеру на: параноїка, епілептоїда, гіпертима, астероїда, шизоїда, психастеноїда, сензитива, гіпотима, конформного, непоступливого, астеніка, лабільного та циклоїда.

Кількість психотипів у Аркадія Егідеса зведено до восьми: паранойяльний, гіпертимний, істероїдний, шизоїдний та епілептоїдний, сензитив, психастеноїд та циклоїд. У Клода Сіго знаходимо чотири типи особистості (темпераменту): дихальний, травний, мускульний та церебральний. За теорією Луїса Леона Терстоуна існує сім типів індивідів: активні, енергійні, імпульсивні, домінантні, стабільні, соціабельні та рефлексивні. Іван Павлов разом із загальними типами (холерик, флегматик, сангвінік, меланхолік) виділяв ще три спеціальні типи: художній, розумовий, змішаний.

Усі ці класифікації-типології є загальновідомими, тож не потребують деталізації та пояснення. Однак класифікація особистостей, запропонована ще на початку XX ст. Олександром Лазурським, $\epsilon$ значущою для нашого дослідження, тож зупинимося на ній більш детально. У своїй праці «Класифікація особистостей» О. Лазурський (Lazurskyi, 1921) писав: 
«Найближчою метою систематичного вивчення індивідуальних характерів $\epsilon$ складання загальноприйнятої класифікації, яка давала б можливість зарахувати будь-яку досліджувану особу до певної групи та була б грунтовним вихідним пунктом для подальшого вивчення людських різновидів». На його думку (Klassifikaciya lichnostej, 1921) ідеальною класифікацією особистостей буде така, що відбиватиме не лише суб'єктивні особливості конкретної людини, а й іiі світогляд і «соціальну фізіологію». В основу теорії особистості Олександром Федоровичем було закладено дві провідні ідеї. Перша ідея: в психіці людини потрібно розрізняти дві сфери: ендопсихіку - внутрішній механізм людської особистості, іiі «цемент», певну нервово-психічну організацію людини, яку інші дослідники часто позначають через поняття темперамент або характер та екзопсихіку - ставлення особистості до зовнішніх об’єктів, середовища.

Друга основоположна ідея: в особистісному розвитку можна виділити три специфічні рівні (психічні), залежно від здатності людини пристосовуватися до соціального середовища, характеристики та сили (ступеня активності) цієї адаптації. Загалом, Олександр Лазурський відзначав (Klassifikaciya lichnostej, 1921), що «будь-яка людина у своєму фізичному й духовному розвитку проходить послідовно цілий ряд певних щаблів, причому кожний наступний щабель характеризується більш багатим і різноманітним душевним життям порівняно 3 попереднім», відтак їх можна розрізнити на нижчий, середній та високий рівень психічного розвитку людини. Узагальнено ці рівні можна представити у такий спосіб:

1) нижчий рівень розвитку характеризується низькою пристосовуваністю особистості до середовища (середовище підпорядковує собі таку людину повністю), наявністю суперечності між можливостями (здатністю) людини самореалізуватися і її професійними знаннями, уміннями й навичками, особистість нездатна до самостійної і незалежної поведінки;

2) середній рівень розвитку характерний для особистостей, більш пристосованих до викликів навколишнього середовища, здатних знайти у ньому своє місце; людина більш свідома, має вищу працездатність та ініціативність, здатна обирати сферу професійної діяльності відповідно до своїх схильностей і задатків;

3) вищий рівень психічного розвитку - особистість на цьому рівні розвитку здатна до швидкої адаптації, пристосування, однак напруженість, інтенсивність душевного життя людини змушує іï відчувати потребу переробити, видозмінити середовище, пристосувати його до власних інтересів, схильностей, можливостей.

Будь-яка особистість може або лишатися на одному рівні, або переходити на рівень вище чи нижче, залежно від іï адаптивності. До основних ознак адаптивності особистості Олександр Лазурський відніс такі:

1) багатство особистості (загальна кількість «психічної продукції» (психічних проявів)), що продукується та демонструється особистістю назовні, iii кількість, розмаїття й складність (або, навпаки, примітивність, бідність, одноманітність); 
2) сила, яскравість, інтенсивність окремих психічних проявів особистості (чим вони сильніші, тим більш здатною адаптуватися є особистість, відтак переходити до наступного рівня психічного розвитку);

3) свідомість та ідейність психічних проявів (чим вища духовна організація людини, тим багатшим та інтенсивнішим душевним життям вона живе, тим стійкішими є іiі моральні, соціальні та ін. принципи);

4) координація психічних елементів між собою (чим досконалішою $\epsilon$ координація та інтеграція цих елементів, тим вищим стає рівень психічного розвитку людини).

I, найголовніше, - Олександр Федорович обгрунтував взаємозалежність психічного типу особистості (рівня психічного розвитку) та іiі професійної діяльності, що, на нашу думку, може стати теоретичною основою розвитку ідеї профілізації особистості людини в процесі іiї професійної підготовки. Перш ніж більш детально обгрунтувати свою думку, представимо типологію особистостей (чисті, комбіновані, спотворені та перехідні типи), запропоновану та обгрунтовану О. Лазурським (Klassifikaciya lichnostej, 1921).

Усі чисті типи особистості можна поділити на три рівні, кожен з яких, у свою чергу, на класифікаційні групи.

I. Нижчий рівень (критерієм поділу є домінантні психофізіологічні функції людини): 1. Розсудливі (попри промовисту назву, характерною для таких осіб є слабка загальна розумова обдарованість на тлі схильності до постійного обмірковування вчинків, схильності до обговорення їх мотивів i наслідків). 2. Афективні (характерною особливістю таких індивідів $\epsilon$ домінування певного афективного процесу, що виявляється у поведінці через рухи (афективний, рухливий), чутливість (чутливий) та фантазії (мрійники)). 3. Активні (залежно від ступеня розвитку окремих сторін вольового процесу поділяються на енергійних нижчого порядку (імпульсивні), покірно-діяльних (зовнішньо директивні) та упертих).

II. Середній рівень (критерієм поділу є співвідношення ендо- та екзорис у структурі особистості): 1. Непрактичні (теоретики-ідеалісти): науковці; художники; релігійно налаштовані споглядачі життя. 2. Практики-реалісти: альтруїсти; громадські діячі; владні; хазяйновиті.

III. Вищий рівень (за критерій поділу було взято міру розвитку екзопсихічних категорій, до яких О. Лазурський відніс загальнолюдські ідеали та їх характерологічні особливості: альтруїзм; знання (індуктивні та дедуктивні); красу; релігію; суспільство; зовнішню діяльність, ініціативу; систему; організацію; владу, боротьбу.

До комбінованих типів О. Лазурський відносив наявність таких особистостей: науково-практичні; науково-суспільні; художньо-практичні; релігійно-адміністративні. Більш детально теорію особистості О. Лазурського представлено й проаналізовано в одній з попередніх наших статей (Leontieva, 2014).

Обговорення. Проаналізовані нами питання методологічних основ профайлінгу, його понятійно-категоріального апарату, генези та основних 
напрямів розвитку, деякі з яких було нами представлено у статті, хоча і не переконали нас остаточно у праві на існування профайлінгу як частини педагогічної теорії та практики, проте відкрили простір для подальших наукових розвідок. Дискусійними лишаються такі питання: рівень науковості цього знання (зауважимо, що науковим $є$ знання, що відповідає критеріям науковості (об'єктивність, системність, перевіреність, орієнтація на передбачення, сувора доказовість, обгрунтованість і достовірність результатів), профайлінг же усе ще більш вірогіднісний метод дослідження, ніж науковий; 3 іншого боку, відсутність науково обгрунтованих верифікованих даних пояснюється значними труднощами у плані розроблення відповідного інструментарію для перевірки точності прогнозів, реконструкцій, портретів, складених профайлерами; вимоги до рівня знань й умінь профайлерів, їх підготовки, а також можливість їх заміни штучним інтелектом; відсутність чіткого та уніфікованого поділу особистостей людей на типи, а відтак складність у створенні їх профілю та прогнозуванні поведінкових патернів; чи може бути покладено в основу педагогічної профілізації особистості (розуміємо це поняття як комплекс взаємопов'язаних діагностичних процедур, що використовується в освітньому процесі для складання психологічного портрету здобувача освіти 3 метою прогнозування його академічної поведінки та подальшої професійної діяльності) теорію особистостей О. Лазурського, яка, на нашу думку, має потенціал для складання динамічного психологічного портрету особистості людини.

Висновки. Таким чином, можемо зробити деякі висновки: профайлінг, безсумнівно, є цікавою (а також актуальною, якщо згадати, що гострий інтерес до цього явища серед населення триває вже понад п'ятдесят років) науковою проблемою, в тому числі для освітньо-педагогічної галузі знань; предмет профайлінгу є міждисциплінарним, тому потребує колаборації дослідників із різних галузей знань; законодавче регулювання цієї діяльності в нашій країні відсутнє, що породжує численні маніпуляції та махінації, які зменшують шанси профайлінгу перерости в галузь наукового знання. Ми свідомі того, що наші висновки не відображають усієї повноти досліджуваної проблеми та запрошуємо до їі подальшого обговорення.

\section{ЛIТЕРАТУРА:}

Мерзликин Й. Значение профайлинга в современном мире. Технология виявлення неконгруэнтности. Научный вестник Московского государственного технического университета гражданской авиащии. М., 2015. № 218. С. 114-116.

Марцева Т. Г. Коммерческий профайлинг как технология управления. Общество и право. 2014. №2 (48). С. 292-294.

Арпентьева М.Р. Экспертный профайлинг как сфера профессиональной деятельности психолога-практика. PEM: Psychology. Educology. Medicine. 2016. №3. С.30-32.

Лазурский А.Ф. Классификация зичностей. Под ред. М.Я. Басова и В.Н. Мясищева. Петроград, 1921. $401 \mathrm{c.}$

Леонтьєва І. В. Теорія особистості О. Ф. Лазурського. Вісник психології і педагогіки. 2014. (1(82)). C. 80-88. 


\section{REFERENCES:}

Merzlykyn, Y. (2015) Znachenie profailinga v sovremennom mire. Tekhnologiya vyayvlenniya nekongruentnosti [The importance of profiling in the modern world. Non-congruence detection technology]. Nauchnyj vestnik Moskovskogo gosudarstvennogo tekhnicheskogo universiteta grazhdanskoj aviacyi. Moskva, № 218. S. 114-116 (in Russian).

Marceva, T. H. (2012). Profailinh kak sovremennaay metodika dsagnostiki biznes-processov [Profiling as a modern method of business process diagnostics]. Vestnik Akademii znanij, (3), 26-30 (in Russian).

Arpenteva, M. R. (2016). Ehkspertnyj profajling kak sfera professionalnoj deyatelnosti psikhologapraktika [Expert profiling as a field of professional activity of a psychologist-practitioner]. PEM: Psychology. Educology. Medicine, (3), 20-32 (in Russian).

Lazurskij, A. F. (1921) Klassifikaciya lichnostej [Classification personalities]. Petrograd. 401 p. (in Russian).

Leontieva, I. V. (2014) Teoriia osobystosti O. F. Lazurskoho [Personality theory O.F. Lazursky]. Visnyk psykholohii i pedahohiky. (1(82)). S. 80-88 (in Ukranian).

\begin{tabular}{|c|c|}
\hline Інформація про авторів: & Information about the authors: \\
\hline Леонтьєва Інна Василівна: & Leontieva Inna Vasylivna: \\
\hline $\begin{array}{l}\text { ORCID iD 0000-0002-8084-1912; кандидат } \\
\text { педагогічних наук, кафедри теорії та історії } \\
\text { педагогіки Київського університету імені }\end{array}$ & $\begin{array}{l}\text { ORCID iD 0000-0002-8084-1912; Candidate of } \\
\text { Pedagogical Sciences, Associate Professor of the } \\
\text { Department of Theory and History of Pedagogy, }\end{array}$ \\
\hline $\begin{array}{llc}\text { Бориса } & \text { Грінченка, } \\
\text { Кудрявська, 18/2, Київ, Україна, } 04053\end{array}$ & $\begin{array}{l}\text { Borys Hrinchenko University of Kyiv, str. } \\
\text { Bulvarno-Kudriavska, 18/2, Kyiv, Ukraine. } \\
04053\end{array}$ \\
\hline e-mail: kubg@kubg.edu.ua & e-mail: kubg@kubg.edu.ua \\
\hline
\end{tabular}

Цитуйте цю статтю як: Леонтьєва I. В.Профайлінг особистості: чи $€$ йому місце в сучасній педагогічній науці?Теорія та методика навчання та виховання. 2021. № 50. C.114-123.

DOI: $10.34142 / 23128046.2021 .50 .10$

Дата надходження статті до редакції: 25.03.2021 p.

Стаття прийнята до друку: 07.04.2021 p. 